Legacy Crystal (Orcid ID: 0000-0002-8687-7297)

Rogers Dallas (Orcid ID: 0000-0002-9359-8958)

Cook Nicole (Orcid ID: 0000-0003-3008-3719)

Ruming Kristian (Orcid ID: 0000-0003-1065-9530)

\title{
Beyond the post-political: is public participation in Australian cities at a turning point?
}

Crystal Legacy,* Dallas Rogers, Nicole Cook, and Kristian Ruming

1 Faculty of Architecture, Building and Planning, The University of Melbourne, Melbourne, Victoria, Australia

2 School of Geography and Sustainable Communities, The University of Wollongong, Wollongong, New South Wales, Australia

3 School of Architecture, Design and Planning, The University of Sydney, Sydney, New South Wales, Australia

4 Department of Geography and Planning, Macquarie University, Sydney, New South Wales, Australia

*Corresponding author: Email: crystal.legacy@unimelb.edu.au

This is the author manuscript accepted for publication and has undergone full peer review but has not been through the copyediting, typesetting, pagination and proofreading process, which may lead to differences between this version and the Version of Record. Please cite this article as doi: $10.1111 / 1745-5871.12304$

This article is protected by copyright. All rights reserved. 


\title{
Beyond the post-political: is public participation in Australian cities at a turning point?
}

\begin{abstract}
This special section builds on Planning the Post-Political City - Part 1 to examine if and how planning is showing signs of a post-democratic turn taking place in Australian cities. In Part 1 we presented a collection of papers examining Australia as a post-political landscape, exploring the new ways in which Australian publics are resisting dominant neoliberal practices and logics of growth, and, in doing so, are intervening in decision-making practices to assert new forms of power and participation. In Part 2 we show how participatory practices continue to evolve. We use this brief editorial to ask a foundational question: have those implicated in the governance and management of Australian cities embarked on a postdemocratic path? As they are presented with new exclusionary and managerial governance systems, the public's participation suggests at the very least that the post-political and postdemocratic condition is neither immutable nor inevitable. However more democratic forms of governance rely on a rich array of activist types and approaches that requires greater institutional support in order to challenge Australia's post-political condition.
\end{abstract}

Keywords: urban politics; post-politics; post-democracy; participation; Australian cities; activism

\begin{abstract}
Technological and cultural change will inevitably lead to incremental change in our constitution and parliamentary practices, but the most urgent task facing Australia is not to invent new democratic structures or to make any specific economic or social change. It is to reinvigorate both the public's democratic engagement and our parliament's enthusiasm for delivering on reforms desired by most Australians. (Denniss, 2018, p.48)
\end{abstract}

In an exposé of the transformational impact neoliberalism has had in Australia, Richard Denniss (2018, p.76), chief economist at the Australian Institute, argues that while 'neoliberalism is dead ... its tired and narrow vision has nearly crushed the life out of 
democracy'. Australians have lost their trust in parliamentarians and our democratic institutions more generally - a loss simultaneously creating a so-called 'democratic deficit'. But the greatest achievement of neoliberal advocates, argues Denniss, has been their ability to present the illusion that there are no alternatives to neoliberalism. Denniss's observations fit in a long trajectory of neoliberal critique that spans a range of fields such as geography (Peck 2010) and urban studies (MacLeod 2011; Metzger 2017), and that embraces more recent post-foundational critique by scholars such as Rancière (1998), Mouffe (2000, 2005) and Žižek (1999). The latter argue that we have now entered a state of post-democracy. In 'depicting the design of policy as having more to do with economic modelling than with national goals and values' (p.57), Denniss strengthens the claim that Australian democratic institutions have been compromised as a result of an embrace by some governments of neoliberal policies and practices over the past thirty years. Emphatically, Denniss also reminds us that 'the lifeblood of democracy is passion and ideas, not spreadsheets and amendments' (p.49).

In citing Denniss's recent essay, we pivot from Part 1 of our two-part special section on Planning the Post-political City in Geographical Research [2018, Volume 56, Issue 2], where we presented a collection of papers examining Australia as a place whereby the post-political condition has taken hold. Part 1 presented papers exploring new ways in which Australian publics are resisting dominant neoliberal practices and logics of growth, and in doing so, are intervening into decision-making practices to assert new forms of power and participation (see Butt \& Taylor 2018; Legacy 2018; MacDonald 2018; McAuliffe \& Rogers 2018; Ruming 2018). Here, in Part 2 of our special section, we build on that discussion to consider if and how planning is showing signs of a post-democratic turn more specifically. We locate the three papers featured in this part of the special section within the broad suite of papers from across the two-part examination of participatory practices in Australian cities. We note that these participatory practices will continue to evolve as they are presented with new exclusionary and managerial governance systems. Finally, we use this brief editorial to ask a foundational question; have those implicated in the governance and management of Australian cities embarked on a post-democratic path? 


\section{A post-democratic turn?}

Economic rationalist reform was rolled out by both major political parties and the governments they formed in both federal and state jurisdictions in Australia over the decades since the 1980s: neoliberal policies thus reshaped Australian cities. This form of economic rationalism has underpinned the privatisation of public transport systems, electricity markets, and urban ports, and precipitated the sell-off of public housing, the retrenchment of the public sector, and the introduction of new public-private partnerships, including those with nongovernment organisations. The subsequent reconfiguration of the relationships between the public and private sectors created new roles for the private sector, as governments increasingly positioned themselves as the managers of large-scale public infrastructure delivery systems rather than as builders or funders of such infrastructure (O'Neill, 2010). In the process, urban development was increasingly valued as an economic process in its own right. In other words, urban development was increasingly valued as a driver of the urban economy rather than as a service to the city. Under the neoliberal mantra of "efficiency and competition", neoliberal ideas and practices reshaped Australian cities in ways that produced new levels of inequality and new forms of uneven spatial organisation (Pawson \& Herath, 2015; Randolph \& Tice, 2014), and introduced new forms of governing the city. Managerial and "outcomes-focused" decision environments reproduce dominant discourses, reinforcing the need to create new jobs and keep the economy growing. These strategies and tactics allow very little room for debate and independent scrutiny, and make it hard for alternative discourses of social justice and ecological sustainability to take hold.

While the advocates of neoliberalism claim that managing people and places by market rule is freedom-producing, there is a large body of work showing that neoliberal systems are almost never fully independent of the state (see, for example, O'Neill \& Fagan, 2006), nor are they liberating for those at the bottom of the socioeconomic structure. Wacquant (2012, p.66), for example, argues that the effects of neoliberal ideas are stratified throughout the population, as the bureaucratic agencies that define and distribute public goods 'spawns a Centaur-state that practices liberalism at the top of the class structure and punitive 
paternalism at the bottom'. Neoliberalism, therefore, has constricted democracy by shaping in critical ways the public's participation in its institutions and the mechanisms by which values are distilled.

While the emergence of participatory planning has produced new spaces for the public's participation, countless studies have shown that these participatory practices are often used to legitimise neoliberal power structures and practices. This effect is in contrast to early ambitions to garner transformative change through the incorporation of participatory practices as a core part of planning decision-making, as articulated by participatory scholars such as Healey (1997) and Innes and Booher (1999). Instead, citizen juries are used in an ad hoc way to advise governments rather than to give citizens the genuine task of deciding policy and priorities. Consultation processes are designed to engage publics early in processes, but then fail to involve them in an ongoing way, when actual investments are being determined. Engagement practices are designed to ask publics about how construction practices can minimise negative impacts on their lives, rather than to engage publics in articulating alternatives to the pressing challenges faced in Australian cities. In each of these instances, the politics of these decision environments are managed by creating tightly designed and managed spaces where questions that unsettle particular forms of power-over and hegemony are foreclosed. Such is what post-foundational scholars describe as postpolitics: reducing democracy to a set of curated and superficially participatory events; 'dumbing down' policy for simple consumption by citizen consumers, and shielding publics from decision-making protected from critical view because of commercial-in-confidence and other legal processes that the neoliberalisation of urban development requires.

\section{Neoliberalism and what counts in the public sphere}

Since the publication of Part 1 of our two-part special section on Planning the Post-Political City in Geographical Research, spotlights have been cast onto the monopolistic practices of multi-billion-dollar corporations such as Facebook and, more locally, Transurban. The two appear to be very different organisations. The former offers a digital platform to connect people, while the latter is a toll road operator. But both are technology and infrastructure 
providers, and both provide valuable illustrations of the profound impacts the private sector is having on the form public participation is taking in cities; and the capacities publics are then afforded to shape decisions about the future of their cities. Below we elaborate on each.

Plenty has been written about the influence Facebook has had on democracy. Citing the election of Donald Trump in the United States, recent analysis shows how democratic preferences are filtered and designed through social media (Allcott \& Gentzkow, 2017). Concerns about echo chambers abound (see Trapenberg Frick, 2016). Facebook also offers a useful illustration of how participation can be siloed into these chambers, preventing debate and contestation in the ways Mouffe $(2000 ; 2005)$ envisaged when theorising politics and plurality. The vigorous debate and deliberation that Habermas (1991) may have envisaged in advancing his idea of the 'public sphere' is undermined, indeed even threatened, in the postpolitical city. What sits underneath a depoliticised social media landscape in Australia is the politically bipartisan acceptance of neoliberalism as the only possibility for further action and, therefore, the associated - if erroneous-understanding that economic rationalism is the only foundation upon which society and government can proceed.

Facebook might be one platform for individuals to share views, and to connect with others, but the rigour and veracity of public debate is lost. Thus, Denniss (2018) argues that public discourse is concealed from the embedded interests that are really shaping Australian cities; and one of the key interests in our cities is the role of private sector actors and their capital and capacity to build large scale infrastructure through complex public-private partnership schemes. It is interesting to us that Denniss also laments the fact that 'Australian politics isn't about ideology [neoliberal or otherwise], it's about interests' (p.18). This claim needs unpacking, which we cannot do here—and which others might like to pick up on.

Less has been written on the toll road operator, Transurban, which owns 15 of 19 toll roads in Australia. Here we turn to work by Bent Flyvbjerg (1998) on the role of power in shaping decision-making, which has served as an important academic intervention into understanding how interests are mobilised. At the time of writing, Transurban is currently being reviewed 
by the Australian Competition and Consumer Commission (ACCC) for anti-competitive behaviour. As a key tenet of neoliberal ideology market-based competition is often invoked to defend neoliberal practices and the (supposed) benefits it serves city planning. Yet, even so, the ACCC's "Statement of Issues" states that 'the proposed acquisition [of Westconnex in Sydney] may substantially lessen competition for concessions to construct, own and/or operate toll roads in NSW or nationally' (ACCC, 2018, p.2). Heeding calls from Marvin and Graham (2002) about the negative impacts of privatisation, and noting the impacts such privatisation may have on holistically and strategically planning for the future of Australian cities (Dodson, 2009), we think the ACCC's review is sobering. It signals in Australia such that the creation of private monopolies is unsettling how we know and understand neoliberalism (Gleeson, 2017). This change sparks many new questions, including those related to the ways in which planning for Australian cities is itself privatised and others about what impact might this have for participation. Where so much of planning has been outsourced to private entities we must examine how the post-political Australian city continues to foreclose politics and participatory democracy, and geographers have a key role to play here.

\section{A post-democratic Australian city}

Jacques Rancière (1998) writes about the state of post-democracy as a turn towards consensus politics. It may be time to consider more fully Rancière's proposition and ask how it might help us understand geography, planning, and public participation in the contemporary city (Inch, 2015; Legacy, 2016; Swyngedouw, 2009). The privatisation of public assets and market-led development schemes are shaping what parts of the city publics can realistically shape via traditional processes of public participation. Strategic plan-making is seen as one way in which those publics can give effect to the visions, priorities, and objectives that might guide future decision-making and investment. But even the collective goals of sustainability, accessibility, and spatial equity are no match for vested interests for whom the city is a site for rent-seeking, commercialisation, privatisation, nor for ideological tensions that play out spatially across different urban geographies. 
A decade after the near-collapse of financial institutions following the global financial crisis of 2007/8 neoliberalism has been surprisingly resilient (Mirowski, 2013). With widespread consensus about market-led planning, questions abound, including ones about the roles the contemporary city plays as a site for socio-political struggle, and the assertion of multispecies rights, access to public space, housing, public transport, or healthy cities. This second special section of Geographical Research joins this chorus by presenting three distinct yet still interlinked accounts of how post-democracy is taking shape and of how public participation is mobilised to contest these trajectories.

We begin with a paper from Shaphan Cox and Tod Jones examining the construction of postpolitical binaries and arguing the need for more dialogical analysis of the post-political. Drawing on the issue of land rights and sovereignty pursued by two Aboriginal groups in Perth, they cast light onto the symbolic violence that arises when post-political binaries are applied in complex and diverse political situations. Cox and Jones ask whether post-political frameworks can contend with the differences experienced within consensus and dissensus politics. In the case of the Southwest Aboriginal Land and Sea Council activists, Cox and Jones argue that engaging in consensus politics has precipitated the production of new forms of institutionalisation, which has allowed greater spatial control over land and greater engagement in formal planning. The paper shows the potential for consensus politics to be transformative arguing that the post-political literature must move beyond its binaries to engage with these moments.

Turning attention to how urban residents act and engage "politically" in the city, Nicole Cook examines the implicit invitation in post-political theory to engage with the agency of bodies and buildings in such settings. Cook highlights new lines of inquiry and analysis that this influence opens up, focusing on the sites and bodies of informal action in the post-political context. Developed by reference to a comparative study of social movement and political activism in Millers Point, Sydney, in the 1970s and 2010s, her paper addresses a significant gap in existing post-political analysis in considering the more-than-human agencies of direct action, drawing post-political theories into dialogue with assemblage and Deleuzian 
scholarship. In doing so, Cook shifts the focus of political geography and critical planning studies beyond social actors, to reconceptualise urban planning and politics as a more-thanhuman assemblage.

Laurel Johnson, Melanie Kwok and Dorina Pojani take a closer look at the planning system itself and consider how a lack of transparency in decision-making has captured community interest and led to activism directed at planning and development. Drawing specifically upon an inner-city neighbourhood in Brisbane, Johnson, Kwok, and Pojani examine stakeholder views about a development that was allowed to proceed even though it did not adhere to the local plan. A motivating factor shaping community activism beyond the formal planning system in this case was the lack of trust and a concern that market-oriented planning was prevailing a perception that was also affecting levels of trust from within the wider community.

These three papers, along with the four published in Geographical Research (2018, Volume 56, Issue 2) draw together our discussions of post-politics in Australian cities. Across the papers important questions are raised about the uneven geographies of public participation across Australian cities. Collectively, the papers highlight both the technologies and discourses that stabilise consensus and the diverse actors and agents through which political debate is staged. A key thread throughout the collection is the importance of social and political movements, mobilised publics, unions, traditional owners, members of wider civil society, and the city itself in maintaining the tradition in liberal western democracies of political debate. Whether such organisations and actors should be required to correct the democratic failure of market-let and the privatisation of planning is an important question. However, the push for consensus as a means of protecting the vested interest of powerful political and economic elite is nonetheless resisted and rendered unstable, albeit unevenly. In a period where the monolithic nature of neoliberal urban governance is reinforced, we can see the need for planning to turn outwards: to support the publics that sustain its rich diversity and progressive foundations against the (post-political) odds. 


\section{References}

ACCC [Australian Competition \& Consumer Commission. 2018. Statement of Issues - 17

May 2018 - Sydney Transport Partners - Proposed acquisition of a majority interest in WestConnex. ACCC. file:///C:/Users/cmlegacy/Downloads/MER18+4542\%20(4).pdf

Allcott, H. and Gentzkow, M. 2017. Social Media and Fake News in the 2016 Election, Journal of Economic Perspectives, 31(2), pp. 211-36.

Butt, A. and Taylor, E., 2018. Smells like politics: planning and the inconvenient politics of intensive peri-urban agriculture. Geographical Research, 56(2), pp.206-18.

Denniss, R. 2018. Dead Right: How neoliberalism ate itself and what comes next. Quarterly Essay, 70 pp.1-79.

Dodson, J., 2009. The 'infrastructure turn' in Australian metropolitan spatial planning. International planning studies, 14(2), pp.109-23.

Flyvbjerg, B., 1998. Rationality and Power: Democracy in Practice. University of Chicago Press, Chicago.

Gleeson, B., 2017. The metropolitan condition. In Planning Metropolitan Australia (pp. 203219). Routledge, London and New York. Ed Freestone, R, Hamnet, S

Graham, S. and Marvin, S., 2002. Splintering Urbanism: Networked Infrastructures, Technological Mobilities and the Urban Condition. Routledge, London and New York.

Habermas, J. and Habermas, J., 1991. The structural transformation of the public sphere: An inquiry into a category of bourgeois society. MIT Press, Massachusetts.

Healey, P. (1997) Collaborative Planning, UBC Press, Vancouver.

Inch, A., 2015. Ordinary citizens and the political cultures of planning: in search of the subject of a new democratic ethos. Planning Theory, 14(4), pp.404-24.

Innes, J. and Booher, D. (1999) Consensus Building and Complex Adaptive Systems, Journal of the American Planning Association, 65(4), pp. 412-23

Legacy, C., 2018. The post-politics of transport: establishing a new meeting ground for transport politics. Geographical Research, 56(2), pp.196-205.

Legacy, C., 2016. Transforming transport planning in the postpolitical era. Urban Studies, 53(14), pp.3108-24.

This article is protected by copyright. All rights reserved. 
MacDonald, H., 2018. Has planning been de-democratised in Sydney? Geographical Research, 56(2), pp.230-40.

MacLeod, G. 2011. Urban Politics Reconsidered: Growth Machine to Post-democratic City? Urban Studies, 48(12), pp. 2629-60.

Mirowski, P., 2013. Never let a serious crisis go to waste. Verso, London.

McAuliffe, C. and Rogers, D., 2018. Tracing resident antagonisms in urban development: agonistic pluralism and participatory planning. Geographical Research, 56(2), pp.219_ 29.

Metzger, J. (2017) Postpolitics and Planning, in Gunder, M., Manipour, A. and Watson, V,. (eds.) The Routledge Handbook of Planning Theory, Routledge, London and New York, pp.180-93.

Mouffe, C., 2000. The Democratic Paradox. Verso, London.

Mouffe, C., 2005. On the Political. Routledge, London and New York.

O’Neill, P.M., 2010. Infrastructure financing and operation in the contemporary city. Geographical research, 48(1), pp.3-12.

O’Neill, P and Fagan, R. 2006. Geographical takes on three decades of economic reform in Australia. Geographical Research.44(2), pp.204-19

Pawson, H. and Herath, S. (2015) Dissecting and tracking socio-spatial disadvantage in urban Australia, Cities, 44, pp.73-85.

Rancière, J., 1998. Disagreement. University of Minnesota Press, Minneapolis.

Randolph, B. and Tice, A. (2014) Suburbanizing disadvantage in Australian cities: sociospatial change in an era of neoliberalism, Journal of Urban Affairs, 36 (sup1), pp.384-99.

Ruming, K., 2018. Post-political planning and community opposition: asserting and challenging consensus in planning urban regeneration in Newcastle, New South Wales. Geographical Research, 56(2), pp.181-95.

Swyngedouw, E., 2009. The antinomies of the postpolitical city: in search of a democratic politics of environmental production. International Journal of Urban and Regional Research, 33(3), pp.601-20. 
Trapenberg Frick, K., 2016. Citizen activism, conservative views and mega planning in a digital era. Planning Theory \& Practice, 17(1), pp.93-118.

Wacquant, L. (2012). Three steps to a historical anthropology of actually existing neoliberalism. Social Anthropology, 20, pp.66-79.

Žižek, S., 1999. The Ticklish Subject: The Absent Centre of Political Ontology. Verso, London. 


\section{University Library}

\section{- M M N E R VA A gateway to Melbourne's research publications}

Minerva Access is the Institutional Repository of The University of Melbourne

Author/s:

Legacy, C;Rogers, D;Cook, N;Ruming, K

Title:

Beyond the post-political: is public participation in Australian cities at a turning point?

Date:

2018-11-01

Citation:

Legacy, C., Rogers, D., Cook, N. \& Ruming, K. (2018). Beyond the post-political: is public participation in Australian cities at a turning point?. Geographical Research, 56 (4), pp.353-357. https://doi.org/10.1111/1745-5871.12304.

Persistent Link:

http://hdl.handle.net/11343/284509 